\title{
Tuberous Sclerosis 2
}

National Cancer Institute

\section{Source}

National Cancer Institute. Tuberous Sclerosis 2. NCI Thesaurus. Code C75331.

Tuberous sclerosis mapped to chromosome 16p13.3 (TSC2 gene). 